\title{
SELF-HELP/MUTUAL-AID CLEARINGHOUSES AND GROUPS IN CANADA: RECENT DEVELOPMENTS
}

\author{
RUBIN TODRES \\ University of Toronto
}

\begin{abstract}
This paper reports on recent developments in the self-help movement in Canada based on the findings of a country-wide survey of self-help clearinghouses and interviews with key informants. Among the outcomes of this survey are an estimate of the number of self-help groups in various communities in Canada as well as a presentation of current trends in the growth of these entities. The author also explores recent fiscal and policy trends in the Canadian context and discusses their impact on the development of self-help groups and clearinghouses in the country.
\end{abstract}

\section{BACKGROUND}

\section{Self-Help Groups}

The Self-Help Resource Centre of Metropolitan Toronto defines self-help groups as:

- a voluntary gathering of people who share common experiences, situations or problems and offer each other emotional and practical support based on the unique perspective only available to those who have shared these experiences

- run by and for group members. Professional providers may participate in the self-help process at the request of the group and remain in an ancillary or consultant role

- entities which include discussion, sharing of information and experiences, and other activities that promote mutual support and empowerment

- open to people who have experienced a common concern

- requiring no charge for participation although a nominal donation or dues may be requested to cover expenses (Self-Help Clearinghouse of Metropolitan Toronto, 1994, p. ii).

Self-help groups are active and growing across Canada. This background paper highlights some successes, challenges, and trends in Canada's self-help groups. In addition, it reports on the evolution of self-help clearinghouses or centres in Canada.

\section{Self-Help Clearinghouses}

and Self-help clearinghouses or centres across Canada are facilitating the growth

development of self-help groups in their cities, regions, and provinees. 
Wollert (1987) refers to these entities as "systems capable of distributing limited self-help resources to the community at large, the professional helping community and to many self-help groups without extensive professional domination of thesc groups" (p. 80).

Clearinghouses ean act as "nerve centres" which deliver a broad range of services and activities in aid of self-help including the publishing of directories and newsletters, consultation to new and existing groups, workshops on topics of interest to self-helpers, and special events aimed at promoting self-help in the general community. Clearinghouses also serve as bridges for increasing communication and collaboration between the self-help and professional communities. In addition, the self-help clearinghouse can act as a vehicle for the grass-roots involvement of people taking charge of their own lives by supporting and being supported by others, and hold great promise as an approach which encourages community-based health promotion and consumer participation.

\section{Methodology}

In the fall of 1995, a (fax and telephone) survey of existing clearinghouses or other organizations performing some clearinghouse functions was completed. In addition, a number of key informants who had knowledge of self-help activities across the country were contacted. This approach led to an identification of the nature of self-help group and clearinghouse activity in the country and an estimate of the number of groups and the trends in self-help group development in Canada. The following is a summary of selected data from the survey.

\section{FINDINGS}

\section{Self-Help Clearinghouses}

At present, there are forms of self-help clearinghouses in 15 cities and in 7 of the 10 provinces in Canada. (Note: Two clearinghouses-Saskatoon and MontreatCAMAC-have been dissolved). While the nature and form of each clearinghouse varies, all minimally provide information and referral services. In addition, there are coalitions of interested individuals in other communities which act as informal resource providers, (e.g., Edmonton and Victoria), while in other communities there appears to be some movement toward developing information centres of clearinghouses (e.g., Woodstock, London, both in Ontario).

In contrast, in 1980 there were only a handful of communities (Ottawa, Calgary, Toronto, and Montreal) performing similar coordination and information functions in Canada. These functions-in the case of Toronto and Montreal-were implemented by volunteers.

\section{Self-Help Groups}

Newsweek magazine (Leerhsen, Lewis, Pomper, Davenport, \& Nelson, 1990) reported there were 500,000 support group meetings in the United States attended by some 15 million Americans, and suggested that the number of these organizations had quadrupled in the 1980s. Others (Powell, 1994: Lieberman \& Snowden, 1993) estimated 7.5 million people in the United States were attending 


\begin{tabular}{|c|c|c|c|c|c|c|c|}
\hline 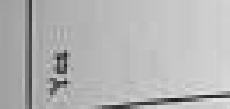 & 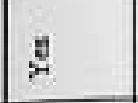 & 주월 & : & ¿ & \& & 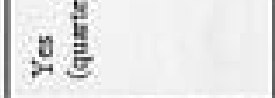 & $\stackrel{*}{*}$ \\
\hline$\nexists$ & 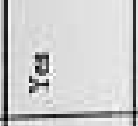 & $\stackrel{3}{-5}$ & $2 \quad \frac{1}{6} \div \frac{1}{2}$ & 3 & 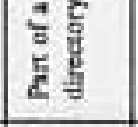 & $\stackrel{-}{x}$ & $\stackrel{\pi}{\pi}$ \\
\hline$\frac{1}{2}$ & 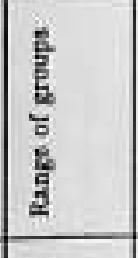 & $\begin{array}{l}\frac{1}{3} \\
\frac{5}{4} \\
\frac{3}{2} \\
\end{array}$ & $\frac{1}{3}$ & 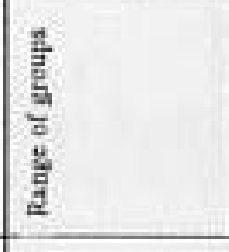 & $\begin{array}{l}5 \\
5 \\
0 \\
0 \\
5 \\
\end{array}$ & 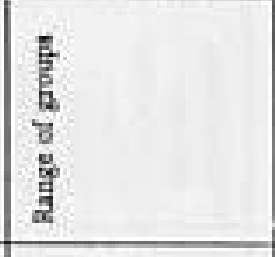 & \begin{tabular}{|l|} 
\\
$\frac{2}{2}$ \\
$\frac{5}{5}$ \\
5 \\
2
\end{tabular} \\
\hline g & 8 & ভ્ & 9 & I & si & 5 & $\therefore$ \\
\hline 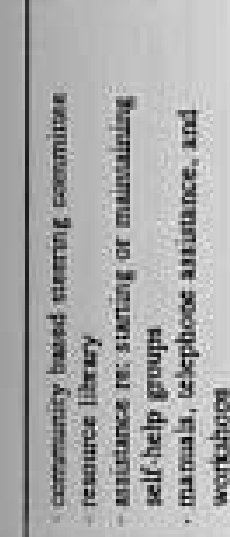 & 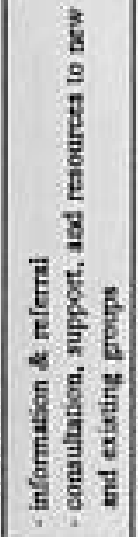 & 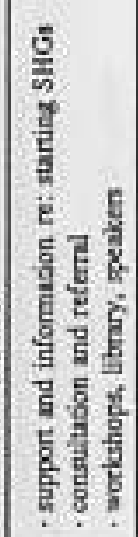 & 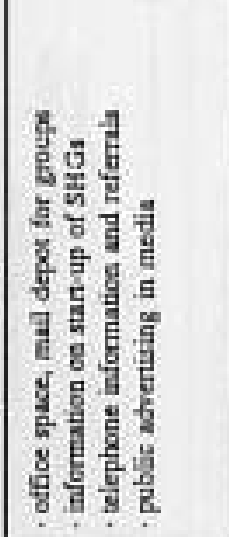 & 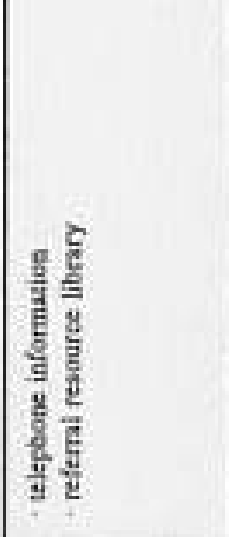 & 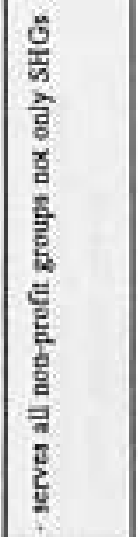 & 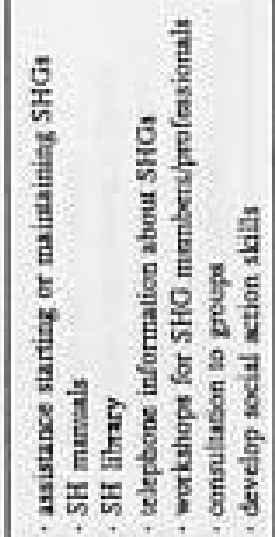 & 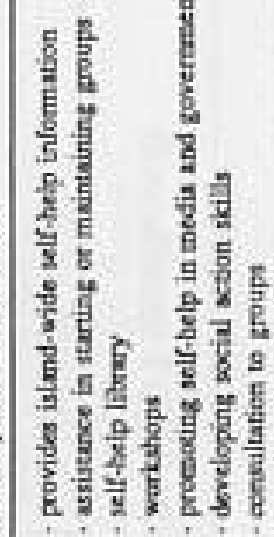 \\
\hline$\frac{y}{2}$ & 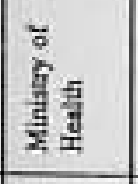 & 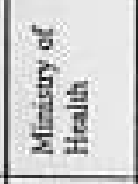 & 趟 & 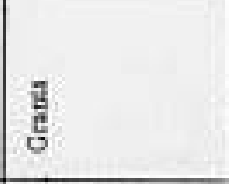 & g & $\frac{3}{2}$ & 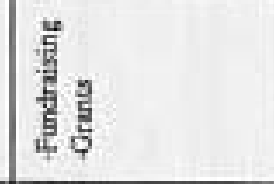 \\
\hline 喜 & 臬 & 종 & 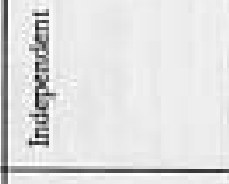 & 离量 & 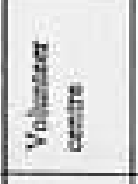 & 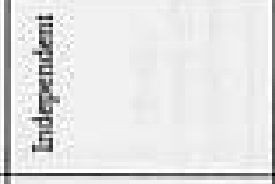 & 旁 \\
\hline 点悬 & छु & 雨要 & 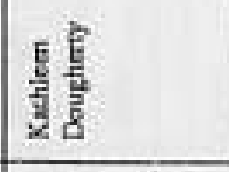 & 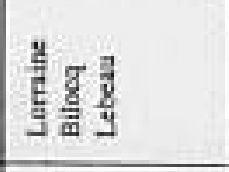 & 豆焉 & 章总 & 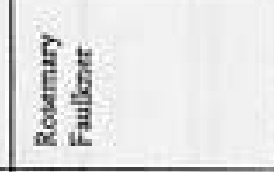 \\
\hline 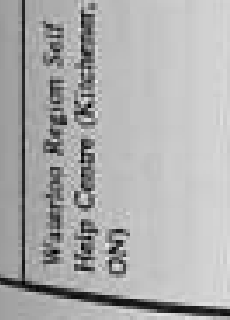 & 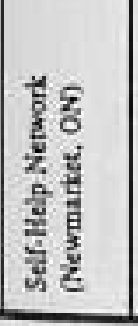 & 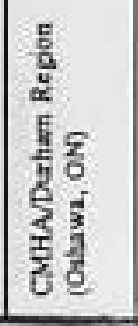 & 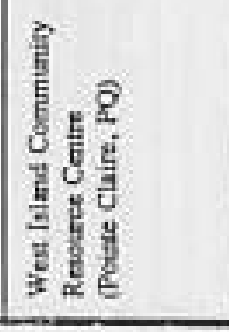 & 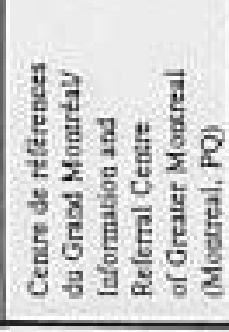 & 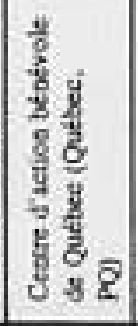 & 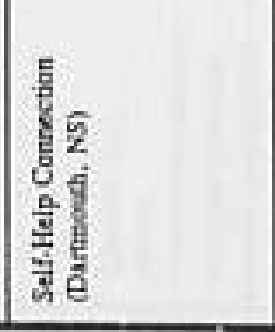 & 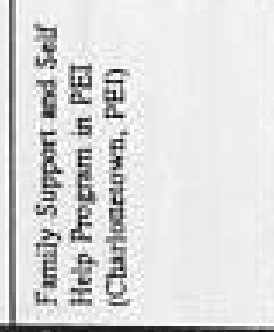 \\
\hline
\end{tabular}




\begin{tabular}{|c|c|c|c|c|}
\hline & 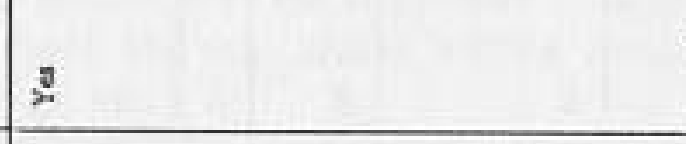 & 2 & 2 & 2 \\
\hline & $\stackrel{x}{2}$ & $\pi$ & $\approx$ & 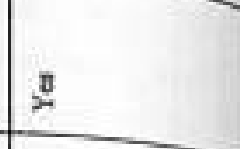 \\
\hline & 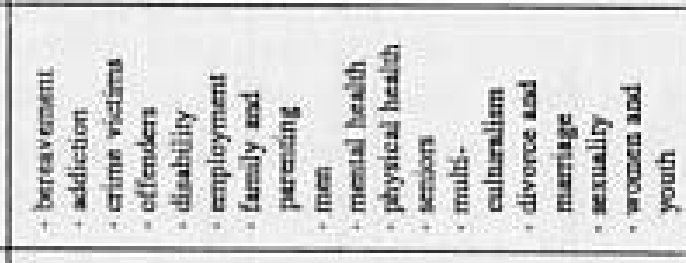 & 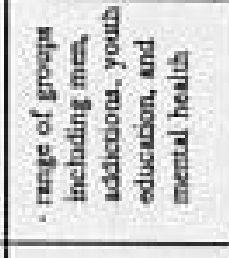 & $\begin{array}{l}\frac{5}{2} \\
\frac{5}{8} \\
\frac{3}{2} \\
\end{array}$ & \begin{tabular}{|l}
$\frac{2}{2}$ \\
$\frac{2}{8}$ \\
$\frac{2}{2}$ \\
$\frac{2}{2}$ \\
\end{tabular} \\
\hline 悬鄫 & 3 & 용 & 8 & $\cong$ \\
\hline & 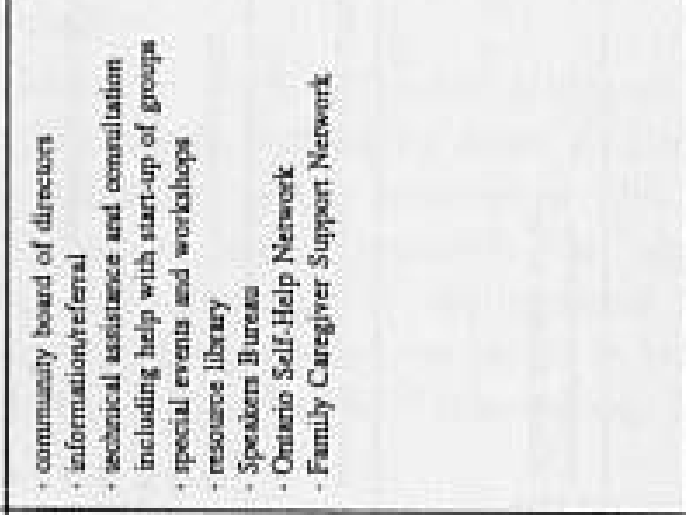 & 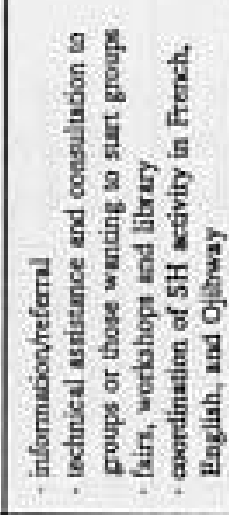 & 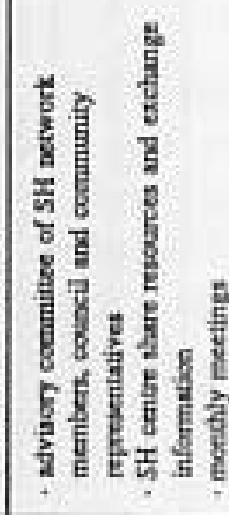 & 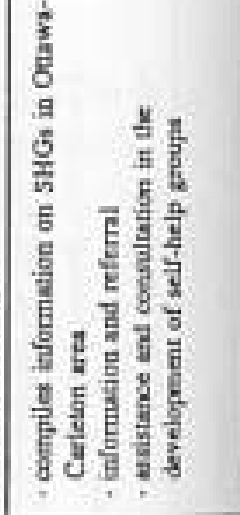 \\
\hline & 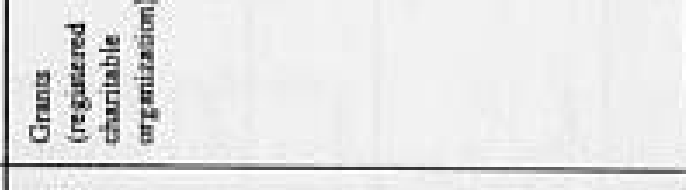 & $\frac{8}{2}$ & $\frac{3}{2}$ & 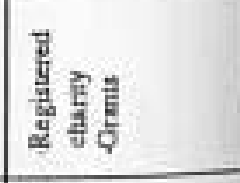 \\
\hline & 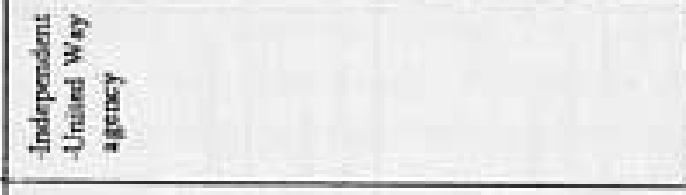 & 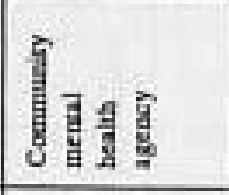 & 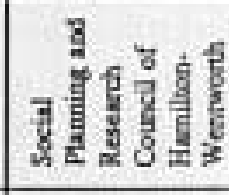 & 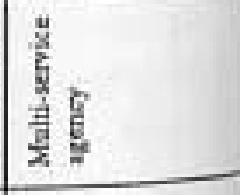 \\
\hline ğ & $\frac{1}{2}$ & 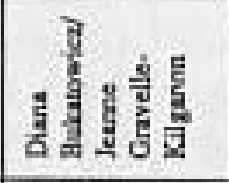 & 煦量 & 量 \\
\hline & 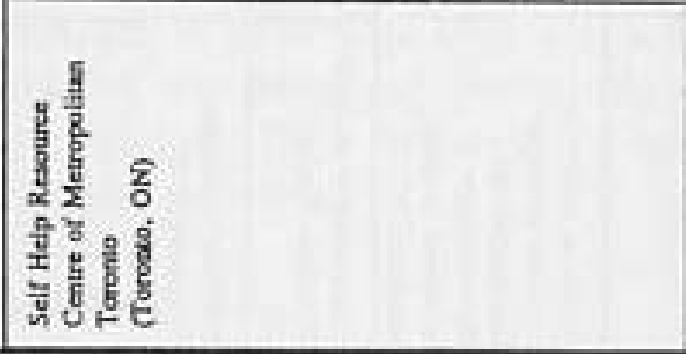 & 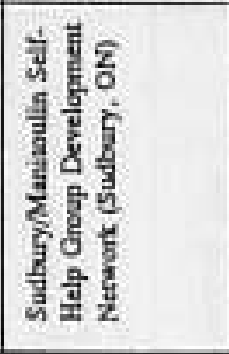 & 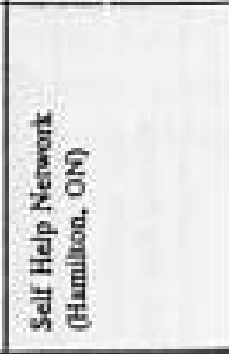 & 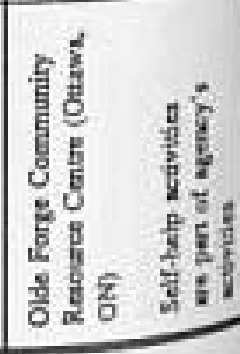 \\
\hline
\end{tabular}




\begin{tabular}{|c|c|c|c|c|c|}
\hline$\frac{2}{2}$ & 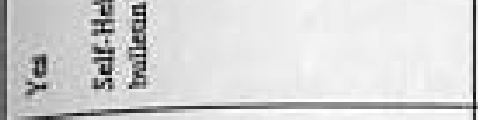 & $\stackrel{2}{2}$ & z & 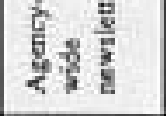 & 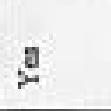 \\
\hline$\frac{5}{2}$ & \$ & 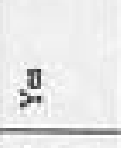 & 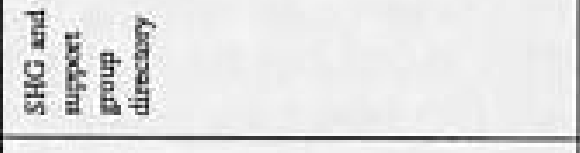 & $\stackrel{2}{2}$ & $\stackrel{5}{-}$ \\
\hline है & 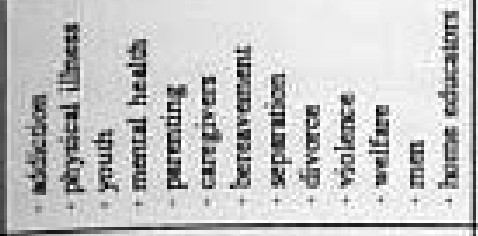 & 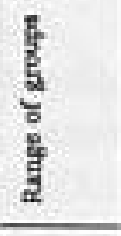 & 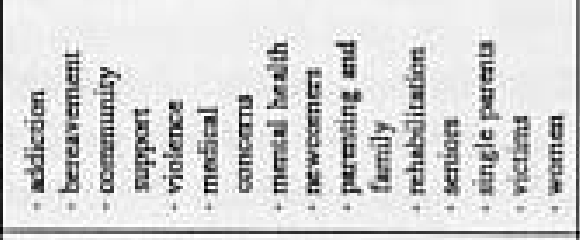 & 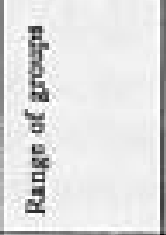 & $\begin{array}{l}\frac{2}{6} \\
\frac{2}{2} \\
\frac{2}{2} \\
\frac{2}{2}\end{array}$ \\
\hline 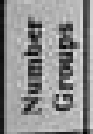 & A & 8 & $\cong$ & $\stackrel{8}{9}$ & $\underline{8}$ \\
\hline & 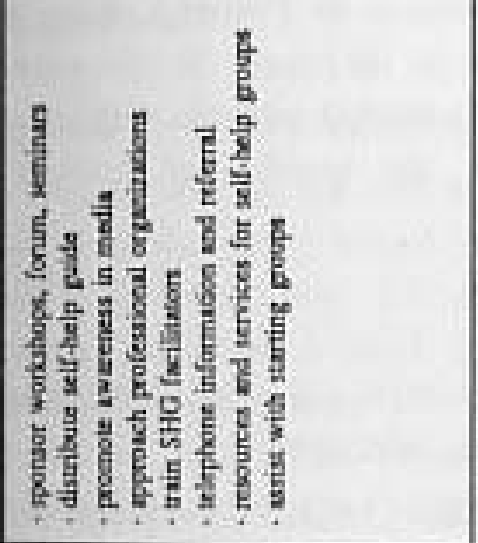 & 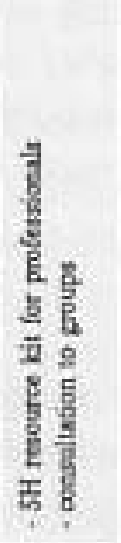 & $\frac{2}{2}$ & 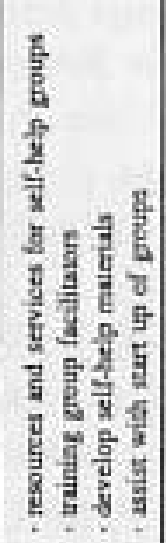 & 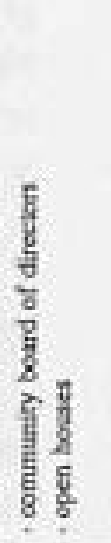 \\
\hline$\underline{E}$ & हू & $\frac{8}{2}$ & $\frac{8}{2}$ & 是 & 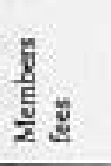 \\
\hline & $\begin{array}{l}\text { J } \\
\text { है } \\
\frac{b}{3} \\
\end{array}$ & 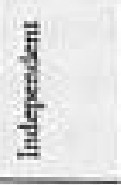 & 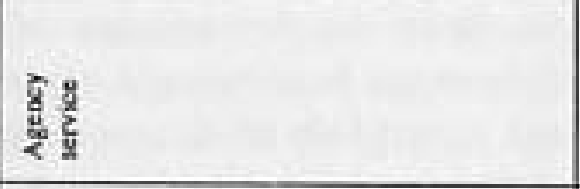 & है & 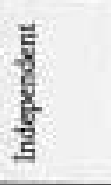 \\
\hline$\frac{5}{8}$ & 믈 & 焉焉 & 频 & $\begin{array}{l}\frac{b}{4} \\
\frac{5}{5} \\
\frac{5}{5}\end{array}$ & 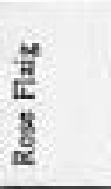 \\
\hline$\frac{1}{5}$ & 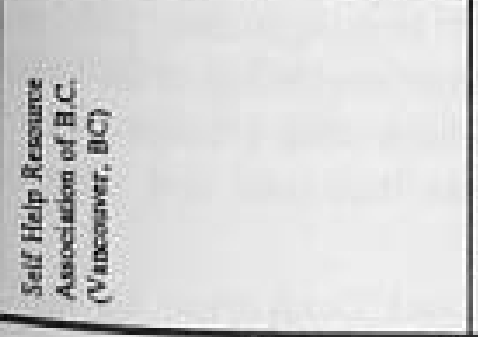 & 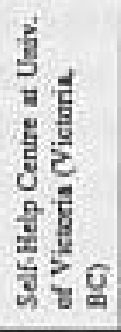 & 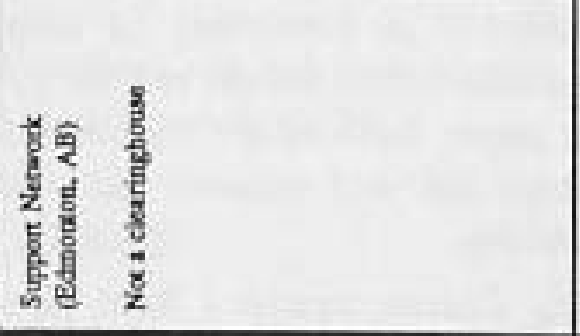 & 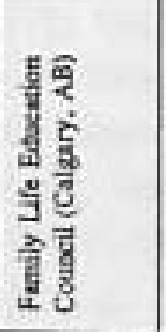 & 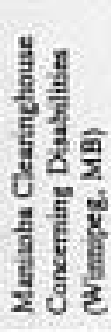 \\
\hline
\end{tabular}


self-help group meetings. In 1987, a report to Health and Welfare Canada sug. gested there were roughly a half-million self-help groups with several million members across North America (Health and Welfare Canada, 1987).

There have been some population surveys done in Canada with estimates of the number of Canadians participating in self-help groups ranging from 299,000) (Romeder, 1993) to 900,000 (Guay, 1989). Gottlieb and Peters (1991) estimated that around 420,000 people are members of some form of a self-help/mutual aid group in Canada.

A 1982 publication entitled Self-Help Groups in Canada (Romeder, 1982), identified the existence of 264 self-help groups in six locations across Canada (Mackenzie, Winnipeg. Ottawa, Montreal, Quebec, and Rimouski). While the author did acknowledge that this survey sample was not representative of all selfhelp groups in Canada, it is interesting to note that this survey of elearinghouses, over a decade later, has identified the existence of more than 3,300 self-help groups across the country. Respondents in such locations as Toronto, Nova Scotia, New Brunswick, and Vancouver have reported large increases in the number of self-help groups in their communities over time. When one considers that some of these groups have multiple chapters or branches, the number of groups could easily be multiplied two or threefold.

\section{Other Canadian Developments}

In addition to the development of clearinghouses in Canada, there have also been some more recent organizational developments, including:

The Ontario Self-Help Network project. The Ontario Self-Help Network Project, initiated by the Toronto Self-Help Clearinghouse in the fall of 1992, is jointly funded by both federal and provincial Health Promotion divisions. Allan Strong, the project director, reports that activities have focused on the promotion of self-help throughout Ontario and organizing community self-help outreach meetings to facilitate the development of local community based self-help networks. These meetings have brought together service providers, self-helpers, and those interested in self-help to discuss ways to share resources, share information about self-help groups, identify barriers to the development of self-help, and identify possible initiatives that could enhance local self-help activity.

Self-Help Canada. Self-Help Canada is a national non-profit network of individuals dedicated to strengthening self-help/mutual aid across Canada. The board of directors is comprised of members of clearinghouses and resource centres, researchers, and human service professionals. According to its chair, Lori Dessau, ${ }^{1}$ the major focus of the organization is on supporting research and educttional programs that will enhance the efforts of clearinghouses and national selfhelp organizations.

Self-Help Canada emerged from an International Conference on Self-Help, held in Ottawa in September. 1992, and marked the end of the five-year mandate of the Canadian Council on Social Development to promote self-help across Canada. To date, Self-Help Canada has sponsored the production of several publications on self-help and mutual aid. 


\section{SUMMARY AND COMMON THEMES}

It appears that the number of clearinghouses and self-help groups has grown considerably in Canada during the last $10-15$ years. There is a sense of momentum and potential for growth of the self-help community in all of the local, regional, or provineial settings that were contacted or surveyed. There are similarities in the kinds of self-help groups that meet actively across the country and some of the trends in group development identified by key contact persons in clearinghouses have common themes. They include: (a) interest in self-help groups for abuse of all kinds; (b) needs of self-help groups members for enhancing skills in group facilitation; (c) concerns about role blurring between professionally led and member-run groups and with it, a hesitancy to become overly involved with professionals; (d) demand for multicultural self-help groups; and (e) a desire on the part of local clearinghouses to connect on a wider regional basis, and the continuing need on the part of provincial clearinghouses to strengthen regional and national networks.

\section{Implications for Policy and Practice}

In Canada during the $1980 \mathrm{~s}$ and in the area of health and social services there has been a discernable trend toward privatization, cut-backs, cost containment, economic efficiency, and the erosion of the principle of universality in social programs at the federal level. It apperas at this juncture that the present federal government is continuing with these trends. Current projections of prospective federal cuts of transfer payments to the provinces for social programs, along with provincial fiscal constraints, suggest future reduction of programs at the provincial level.

Therefore, notwithstanding the growth in the number of self-help groups and clearinghouses in Canada, social policy statements supporting self-help from various levels of governments have remained as broad commitments to policy frameworks and generally have not been translated into direct programs. For example, there does not appear to be a national perspective concerning self-help in Canada. That is, while support for individual self-help groups, programs, or organizations can be identified across the country, it has been time limited and has often taken the form of demonstration or research grants rather than sustained operational funding. While governments may appear to be intrigued with the intuitive appeal of self-help, they are not prepared to make trade-off decisions to fund self-help at the cost of existing programs. Competition in the voluntary sector for scarce public dollars is increasing. Therefore self-help organizations remain in a dependent and precarious situation and their future is unclear.

\section{LIMITATIONS}

This paper has reported on the state of self-help in Canada as determined by the results of a survey of key informants in Canada. Many of the key informants Were already known to the author or were identified by the use of a "snowballing technique." Yet it is possible that some self-help activities in the country may not have been known by the "key informants" in this study and therefore were not 
noted in the study. Finally, the observations concerning policy trends in Canada were based on observations from Ontario and may not necessarily be as true in other parts of the country, nor were they empirically verified.

\section{NOTES}

1. Mailing address: clo P.O. Box 64094, 1620 Scott St., Ottawa, ON KIY 4 V1 (as of September, 1995).

\section{RÉSUMÉ}

L'évolution des organismes d'entraide au Canada est l'objet de ce texte. Une enquête nationale auprès des centres d'information sur les groupes d'entraide ainsi que des entrevues auprès d'informateurs-clés ont permis de fournir ce portrait. On peut tirer de cette recherche des estimations sur le nombre de groupes d'entraide ainsi que certaines tendances concernant leur croissance.

\section{REFERENCES}

Gottlieb, B.H., \& Peters, L. (1991). A national demographic portrait of mutual aid participants in Canada. American Joumal of Community Psychology, 19(5), 651-666.

Guay, J. (1989). Self-help groups in Canada. A profile of volunteers based on the 1987 national survey on volumteer activity. Ottawa: Secretary of State.

Health and Welfare Canada. (1986). Ottann charter for health promotion. Procesdings from an International Conference on Health Promotion, Ottawa.

Health and Welfare Canada. (1987. November). Mutual aid as a mechanism for health promotion and disease prevention. Ottawa: Author.

Lieberman, M.A., \& Snowden, L.R. (1993). Problems in assessing prevalence and membership characteristics of self-help participants. Joumal of Applied Beftaworal Science, 29(2), 166-180.

Leerhsen, C., Lewis, S.D., Pormper, S., Davenport, L., \& Nelson, M. (1990, February 5). Unite and conquer. Newsweek, 50-55.

Powell, T. (1994). Understanding the self-help organization. New York: Sage.

Romeder, J.-M. (1993). Of surveys and definitions of self-help and mutual aid. In M. Stewart \& F. Lavoic (Eds.), Self-help/mutual aid for seniors: Research challenges (pp. 511). Ottawa: Self-Help Canada.

Romeder, J.-M. (1982). Self-help groups in Canada, Otawa: Health and Welfare Canada.

Self-Help Clearinghouse of Metropolitan Toronto. (1994, May). A directory of self-help? mutual aid groups in Metropolitan Toronto. Toronto: Author.

Wollert, R. (1987). Human services and the self-help clearinghouse concept. Canadiant Journal of Communiry Mental Health, 6(1), 79-90. 